\title{
Identification of Tourism Potential and Investment Strategy- A Case Study of Banyuwangi Regency.
}

\author{
MURNIATI ${ }^{1}$, GHOZALI MASKI ${ }^{2}$, ISWAN NOOR ${ }^{3}$, MARLINA EKAWATY $^{4}$ \\ ${ }^{1}$ Bina Nusantara (BINUS) University and Student of Doctoral Program in Economics at UNIVERSITAS BINA \\ NUSANTARA and UNIVERSITAS BRAWIJAYA, INDONESIA. E-mail: murniati@binus.ac.id \\ ${ }^{2}$ Faculty of Economics and Business of UNIVERSITAS BRAWIJAYA, INDONESIA. E-mail: ghozalimaski@ub.ac.id \\ ${ }^{3}$ Faculty of Economics and Business of UNIVERSITAS BRAWIJAYA, INDONESIA. E-mail: iswan@ub.ac.id \\ ${ }^{4}$ Faculty of Economics and Business of UNIVERSITAS BRAWIJAYA, INDONESIA. E-mail: marlina@ub.ac.id
}

\begin{abstract}
Tourism as one of the potential resources in Indonesia significantly affects the country's development. However, it has not been well-managed due to many obstacles such as financing, promotion, and natural disasters. This study aimed to identify tourism attractions in Banyuwangi Regency as a newly developing district in Indonesia. The quantitative approach with the descriptive analysis applied in this study indicated that that the leading tourist attractions in Banyuwangi have excellent economic growth potential and good financial ratios. Based on the results of Financial Analysis analyzed through variables Payback Period (PP), Average Rate of Return (ARR), Net Present Value (NPV), Internal rate of Return (IRR), and Profitability Index (PI), Banyuwangi has the potential feasible for investment in the tourism sector. This research would provide further consideration for investors before investing in the tourism sector in Banyuwangi Regency.
\end{abstract}

Keywords: Economic development; Investment strategy; Tourism; Potential identification.

JEL Classification: G31, L26, P25 


\title{
Identificación del Potencial Turístico y Estrategia de Inversión - Un Estudio de Caso de la Regencia de Banyuwangi.
}

\author{
MURNIATI ${ }^{1}$, GHOZALI MASKI ${ }^{2}$, ISWAN NOOR ${ }^{3}$, MARLINA EKAWATY ${ }^{4}$ \\ ${ }^{1}$ Bina Nusantara (BINUS) University and Student of Doctoral Program in Economics at UNIVERSITAS BINA \\ NUSANTARA and UNIVERSITAS BRAWIJAYA, INDONESIA. E-mail: murniati@binus.ac.id \\ ${ }^{2}$ Faculty of Economics and Business of UNIVERSITAS BRAWIJAYA, INDONESIA. E-mail: ghozalimaski@ub.ac.id \\ ${ }^{3}$ Faculty of Economics and Business of UNIVERSITAS BRAWIJAYA, INDONESIA. E-mail: iswan@ub.ac.id \\ ${ }^{4}$ Faculty of Economics and Business of UNIVERSITAS BRAWIJAYA, INDONESIA. E-mail: marlina@ub.ac.id
}

\begin{abstract}
RESUMEN
El turismo, como uno de los recursos potenciales de Indonesia, afecta significativamente al desarrollo del país. Sin embargo, no ha sido bien gestionado debido a muchos obstáculos como la financiación, la promoción y los desastres naturales. Este estudio tiene como objetivo identificar las atracciones turísticas de la regencia de Banyuwangi, un distrito de reciente desarrollo en Indonesia. El enfoque cuantitativo con el análisis descriptivo aplicado en este estudio indicó que las principales atracciones turísticas de Banyuwangi tienen un excelente potencial de crecimiento económico y buenos ratios financieros. Basándose en los resultados del análisis financiero analizado a través de las variables Periodo de Retorno (PP), Tasa Media de Retorno (ARR), Valor Actual Neto (NPV), Tasa Interna de Retorno (IRR), e Índice de Rentabilidad (PI), Banyuwangi tiene el potencial factible para la inversión en el sector turístico. Esta investigación proporcionará una mayor consideración a los inversores antes de invertir en el sector turístico en la Regencia de Banyuwangi.
\end{abstract}

Palabras clave: Desarrollo económico; Estrategia de inversión; Turismo; Identificación del potencial.

Clasificación JEL: G31, L26, P25

Recibido: 29 de Junio de 2021

Aceptado: 01 de Octubre de 2021 


\section{Introduction}

The tourism sector as the locomotive of economic growth for the people empowerment in Banyuwangi is growing up, reaching $10 \%$, being a multiplier effect on other sectors. (Putri, 2015). It has a significant positive impact on economic growth, as quality research results revealed, and information and communication technology (ICT). Policymakers should consider the factors to propose measures to stimulate economic growth through tourism sector channels (Tang, 2021).

Currently, each region must do its best to increase its income. Exploring regional economic potential and using the right potential is the best way to achieve optimal results. Regional economic potential means the economic capacity that exists in the area that is possible and feasible to be developed to be a source of livelihood for the local people that can help their economic lives sustainably (Lasindrang, 2015) (Ghazoul et al., 2010)

Investment plays a critical role in the economic life of the nation in terms of capital formation. It can expand production capacity, increase local revenue, and create new jobs, which, in turn, will expand employment opportunities. One component of the GDP is investment expenditure. In this context, investment functions as fixed capital formation (Gross Fixed Capital Formation) plus changes in stocks (Increase in Stock). Per capita income is one measure of the prosperity of a region. The higher a person's income, the higher the real per capita income of a region, the greater the ability of the local community to finance routine expenditures and government development expenditures. Community income shows the community's ability to pay the expenses (Skidmore \& Scorsone, 2011). Investment in tourism is very important. Indonesia has so many tourist attractions but many of them are under poor management due to limited financing, management, marketing, and resources. Furthermore, no sufficient information on which tourism objects are profitable for investors regarding investment feasibility is available. The importance of investment according to (Kee et al., 2019) as happened to Huawei technology co., Itd. invest heavily in basic research, concentrating on technological breakthroughs that drive sales globally for future success. This should be encouraged by improving manufacturing processes and innovating new technologies for competitive advantage to improve quality (Al Mudhayan et al., 2019).

The tourism sector contributes to economic diversification by developing other industries such as construction, communication, trade, agriculture, consumer goods production, national crafts, and others. With an understanding of the existing situation that can be used by stakeholders to strategize development plan (Pusparajan et al., 2020). Banyuwangi Regency, which is developing rapidly in East Java, needs to map which tourist objects need investment. This study aims to identify the prime tourist attraction in Banyuwangi Regency to provide an illustration to assist investors in their consideration before investing their capital.

\section{Literature Review}

\subsection{Regional Potential}

Potential is a great resource hidden and undiscovered at the time of human birth in this world. It has not been found, strongly covered, untouched, unused, and hidden. In other words, it is an ability, strength, or power, which can be innate or talent and results of stimulus or training (Rizaly \& Rahman, 2021). It is the ability, strength, ability, and power that are possible to develop. Tourism can be an important livelihood option and conservation incentive for communities. Significant benefits from tourism development are in the form of increased employment, financial profits, infrastructure creation, cultural revitalization, and environmental protection (Bennett et al., 2012).

\subsection{Tourism}

Indonesia is an archipelagic country that has abundant natural resource potential and a variety of distinctive regional ethnic cultures. This potential strongly supports the development of one of the 
national strategic sectors, namely the tourism sector. According to M.Liga Suryana and Vanny Octavia (2015), tourism is a variety of tourism activities and is supported by various facilities and services provided by the community, entrepreneurs, central government, and/or regional governments. The World Tourism Organization (WTO), in Wiweka \& Arcana (2017), defines tourism as traveling to and staying in place outside the usual environment for not more than one consecutive year for leisure, business, and other purposes.

One of the challenges facing Indonesia is the limited investment and limited professional workforce for the tourism sector. According to Knollenberg et al. (2021), the tourism workforce is a very important resource in the success of tourism businesses and destinations. However, they often experience social, psychological, and economic pressures leading them to suffer from isolation by the destination community or limited interest in participating in the tourism workforce. These threaten the sustainability of tourism businesses and destinations. Moreover, what is even more threatening is creating an unfair or unsafe work environment for employees. The community capital framework needs to identify the resources currently supporting the tourism workforce in island communities whose economic and social structures are heavily dependent on tourism. One way to succeed in tourism is with social, cultural, human, and natural capital assets that are used to support the tourism workforce to help maintain it.

Tourism is one of the fastest-growing economic sectors in the world that provides benefits to local communities and destination areas (Murphy, 2013). It contributes to economic growth through various channels including foreign currency income, attracting international investment, increasing tax revenue, and creating additional jobs (Li et al. (2018). According to the World Tourism Organization (WTO), tourism is a human activity of traveling to and living in a destination outside of their daily environment.

\subsection{Investment}

Investment is made for one or more assets owned and usually for a long period with the hope of getting profits in the future. Based on economic theory, it means the purchase (and production) of capital goods that are not consumed but are used for future production (Sunariyah, 2013). Law No. 25 of 2007 concerning Investment explains that investment is all forms of investment activities, both by domestic investors and foreign investors, to conduct business in the territory of the Republic of Indonesia.

Keynes in Basila (2010) viewed the government as an independent agent capable of stimulating the economy through public work. Expansionary government policies can increase "effective demand" if resources are used without harming consumption or investment. During a recession, an increase in government expenditure (G) will encourage an increase in consumption (C) and investment (I) and, thus increasing GDP (Y). Harrod-Domar in Indrajaya \& Devi (2014) developed Keynes' theory by giving investment a key role in the process of economic growth, especially regarding the dual nature of the investment: first, investment creates income (which is the impact of investment demand) and, secondly, investment increases the production capacity of the economy by increasing the capital stock (which is the impact of investment supply). Uzbekistan is taking active steps to create a favorable investment climate. At the heart of this are two fundamental factors: stability and sound and balanced macroeconomic policies. Investment policy in Uzbekistan is aimed at solving strategic problems (Axmedova, 2020)

In developed countries, the largest investor comes from the private sector, which holds very large economic activity (investment). The economies of developed countries are highly supported by the private sector, which is commonly referred to as a market economy. In developing countries, the government sector usually still plays the main role in the economy, as seen by its strict supervision. The government invests primarily to increase national income. Government investment is made in the form of expenditures/purchases to built or provide public infrastructure commonly called public goods, including roads, schools, hospitals, irrigation projects, and other infrastructure development. 
The private sector makes investment expenditures aimed at increasing production capacity for profit only. Due to the limited capacity of the government, investment inequality in various development sectors occurs. As a result, some sectors are left behind in development. Investment in regional development can be a source of capital, increase employment opportunities, and transfer technology.

\section{Methodology}

Based on the background and purpose of this study, namely to identify the leading tourist attractions in Banyuwangi Regency to provide an illustration to assist investors in investing their capital and the readiness of existing funds, the most appropriate approach was a quantitative descriptive approach. The types of data used in this study were primary and secondary data. Primary data is information obtained from primary sources, namely information from informants (Sugiarto, 2017), collected directly through interviews and direct field surveys. Meanwhile, secondary data is information obtained not directly from the primary sources but from third parties (Sugiarto, 2017) like agencies and other parties related to other studies. The data used in this study included GRDP data, tourist visit data, and other data used in financial analysis, as well as the results of a couple of research done by the Central Bureau of Statistics and the local government of Banyuwangi Regency.

This research was conducted by collecting data from a population sample and then analyzing it using statistical methods used to interpret. The sample used in this study was a total of 11 tourist attractions in Banyuwangi that have been determined by the Banyuwangi Regency Government RUPM (General Investment Plan). The sample collection technique was the purposive sampling method based on certain characteristics in a population with a dominant relationship to achieve research objectives (Lopez \& Whitehead, 2013); Kim et al., 2017). The method used was to collect, record, and review data that had been officially provided.

Operational variables of this research were the attribute or nature or value of a person, object, or activity with certain variations determined by the researcher to be studied and to conclude. The operational variables in this research are:

1. Market needs are the number of potential markets/consumers needed by (prospective) investors in running tourism business in Banyuwangi.

2. The prospect of tourism investment is the prospect of the Banyuwangi tourism service business.

3. Financial Analysis in this research involved:

a. Payback Period (PP), a technique for assessing the project investment returns period or effort.

b. Average Rate of Return (ARR), to measure the average return on interest by comparing the average profit after tax (EAT) with the average investment.

c. Net Present Value (NPV), the ratio of Net Cash PV (PV of proceeds) to investment PV (capital outlays) during the investment. The difference between the two PVs is what we know as Net Present Value (NPV).

d. Internal rate of Return (IRR), a tool to measure the rate of return of internal results.

e. Profitability Index (PI), or cost ratio, the activity ratio of the total present value of net revenues with the present value of investment expenditures over the life of the investment.

The data Analysis methods used to answer problems and achieve goals are as follows:

\section{Analysis of the Potential Growth of the Economic Sector}

This analysis aimed to observe the development of the potential capacity of the economic sector (tourism business), both by type and producing location. The formula for calculating the number of potential developments for this tourism business can be written as follows:

$$
\Delta S i=\frac{S_{n}-S_{n}-1}{S_{n}-1} X 100 \%
$$


in which:

$\mathrm{Sn}=\mathrm{PDRB} n=$ tourism sector value in the last year

Sn-1=PDRBn-1= tourism sector value in the early year

\section{Analysis of the Level of Market Demand for the Tourism Sector}

This analysis was used to measure the level of market demand for tourism products/services. Potential demand was determined by calculating the projected demand for livestock products (XDi*) with the following model:

$$
X_{D^{*}}=a+b 1 X 1+b 2 X 2+b 3 X 3+\ldots . b k X k .
$$

in which:

- $\mathrm{X}_{\mathrm{Di}^{*}} \quad$ : projected Demand in the tourism sector

- a : constant

- bxi $\quad$ : coefficient of variable Xi

- $x i$ : variable Xi

\section{Financial Analysis}

This analysis was used to determine the feasibility of a business development project using the following five analytical tools.

\section{a. Payback Period (PP)}

There are two models of assessing the period of return on investment in a project or business:

- If the net cash every year is the same

$$
\mathrm{PP}=\frac{\text { Investment }}{\text { Net Cash/Year }} \times 12 \text { month }
$$

- If the net cash each year is different

$$
\mathrm{PP}=\frac{\text { Investment }}{\text { Net Cash after the period ends }} \times 12 \text { month }
$$

To assess whether a business is acceptable or not based on the PP, the results of the calculation must be as follows:

1. Current PP is less than the investment period.

2. By comparing the average of similar business units.

3. In accordance with company targets.

\section{b. Average Rate of Return (ARR)}

Average Rate of Return is used to measure the average return on interest by comparing the average earnings after tax (EAT) with the average investment. The formula for calculating ARR is as follows:

$$
\begin{aligned}
& \text { - ARR \% = } \\
& \text { Average investment } \\
& \text { - Average EAT = } \underline{\text { Total EAT }} \\
& \text { Economic life ( } n \text { ) }
\end{aligned}
$$




\section{c. Net Present Value (NPV)}

Net Present Value is a comparison between Net Cash PV (PV of proceeds) and investment PV (capital outlays) during investment. The difference between the two PVs is known as the Net Present Value (NPV). The formula is as follows:

$$
\begin{aligned}
& \text { NPV } \left.=\frac{\text { Net Cash } 1}{(1+r)}+\frac{\text { Net Cash 2 }}{(1+r)^{2}}+\ldots+\frac{\text { Net Cash N }}{(1+r)}-\text { Investment }\right) \\
& \text { NPV }=\frac{\text { Net Cash 1 }}{(1+r)}+\frac{\text { Net Cash 2 }}{(1+r)^{2}}+\ldots+\frac{\text { Net Cash N }}{(1+r)} \text {-Investment }
\end{aligned}
$$

After obtaining a results with:

- positive NPV, then investment is acceptable;

- negative NPV, then investment is rejected.

\section{d. Internal rate of Return (IRR)}

It is a tool for measuring internal rate of return.

$$
\text { Formula }=P I-C 1 X \frac{P 2-P 1}{C 2-C}
$$

in which

$$
\begin{aligned}
& \mathrm{P} 1=\text { interest rate } 1 \\
& \mathrm{P} 2=\text { interest rate } 2 \\
& \mathrm{C} 1=\mathrm{NPV} 1 \\
& \mathrm{C} 2=\mathrm{NPV} 2
\end{aligned}
$$

with the following terms:

1) If the IRR is greater than the loan interest, then it is accepted;

2) If the IRR is less than the loan interest, it will be rejected.

\section{e. Profitability Index (PI)}

Profitability index or benefit and cost ratio is the ratio of the activity of the total present value of net revenues to the present value of investment expenditures over the life of the investment.

$$
\text { Formula }: P I=\frac{\sum \text { PVNet Cash }}{\sum \text { PVinvestment }} X 100
$$

\section{Results and Discussion}

\subsection{Analysis of Economic Sector Potential Growth}

Banyuwangi Regency has an area of $5,782.40 \mathrm{~km}^{2}$, the widest among regencies and cities in East Java Province, Indonesia. It has great potential in agriculture, plantations, and fisheries, and has attractive, natural, and popular tourist attractions. 
Table 1 Banyuwangi Regency Economic Growth in 2011-2017

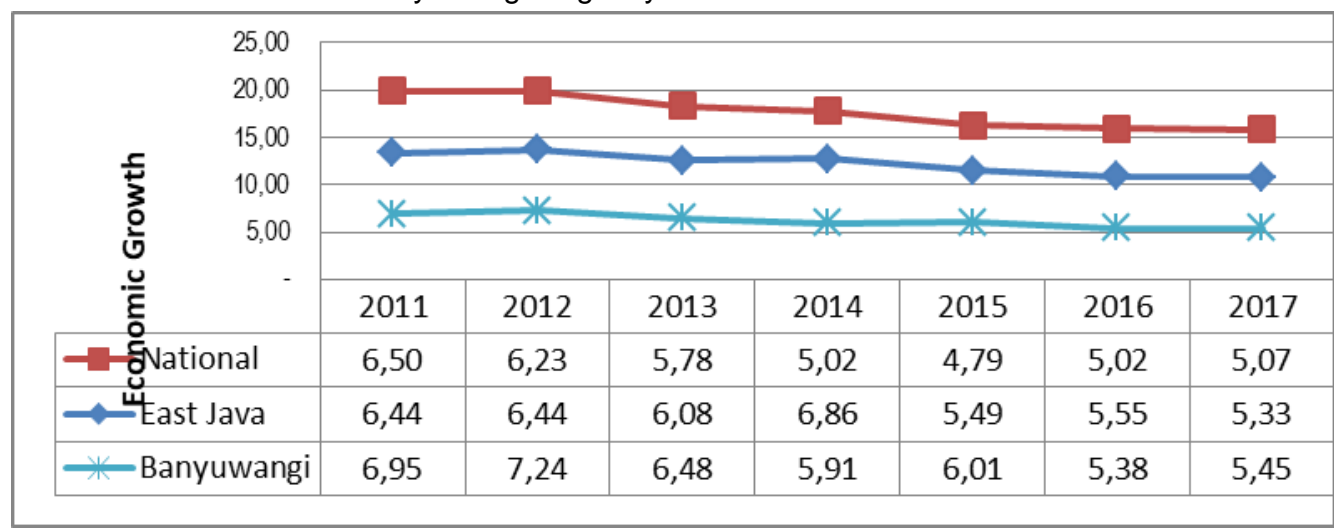

Source: (Badan Pusat Statistik Indonesia, 2021)

Another effort made by the government in encouraging economic growth is to create a conducive investment climate. Investments that enter a region will encourage and grow economic activity, especially in the real sector, which in turn will increase the production output. This increase in production output will encourage increased income and economic growth. The following is the development of investment realization in Banyuwangi Regency in 2018:

Table 2 Data on Investment in Banyuwangi Regency in 2018

\begin{tabular}{|c|c|c|c|c|}
\hline \multirow[b]{2}{*}{ No. } & \multirow[b]{2}{*}{ Type of Investment } & \multirow{2}{*}{$\begin{array}{l}\text { Number } \\
\text { of License }\end{array}$} & \multicolumn{2}{|l|}{ Realization } \\
\hline & & & $\begin{array}{c}\text { Investment Realization } \\
(\mathrm{Rp})\end{array}$ & $\begin{array}{c}\text { Labor } \\
\text { (Person) }\end{array}$ \\
\hline 1 & Foreign investment & 14 & 31.405 .050 .000 & 628 \\
\hline 2 & Domestic investment & 9 & 689.991 .600 .000 & 13,800 \\
\hline 3 & Non-Facility Investment & 1,285 & 3.825.109.346.301 & 62,074 \\
\hline & & 1,308 & 4.546 .505 .996 .301 & 76,502 \\
\hline
\end{tabular}

Based on Table 2 above, the development of investment realization in Banyuwangi Regency in 2018 is divided into three types of investment: Foreign, Domestic, and Non-facility Investments, each amounting to Rp31,405,050,000, Rp689,991,600,000, and 3.825.109.346.301, bringing the total to Rp4.546.505.996.301. Opportunities to make invesments in the tourism sector in Banyuwangi Regency are very open along with various tourism development innovations carried out jointly by the government, the business world, and the community for the development of the tourism sector, economic growth, and environmental and cultural preservation of Banyuwangi. Tourism development in Banyuwangi is carried out in an integrated, interconnected, and mutually positive impact, going hand in hand.

\subsection{Analysis of sector potential}

Another supporting aspect in the economic development of Banyuwangi Regency is its very strategic location on the eastern tip of the island of Java which has a million extraordinary natural charms. In addition, it lies on the direct border with the Bali Strait. Many visitors to the island of Bali then continue their tour to Banyuwangi. According to Fikri (2017), Banyuwangi is dubbed "The Sunrise of Java." The tourist areas are diverse, consisting of lowlands to highlands, mountainous areas, and beaches, as well as historical sites and other ancient heritage sites. 
Figure 1 Potential Tourism Objects in Banyuwangi Regency

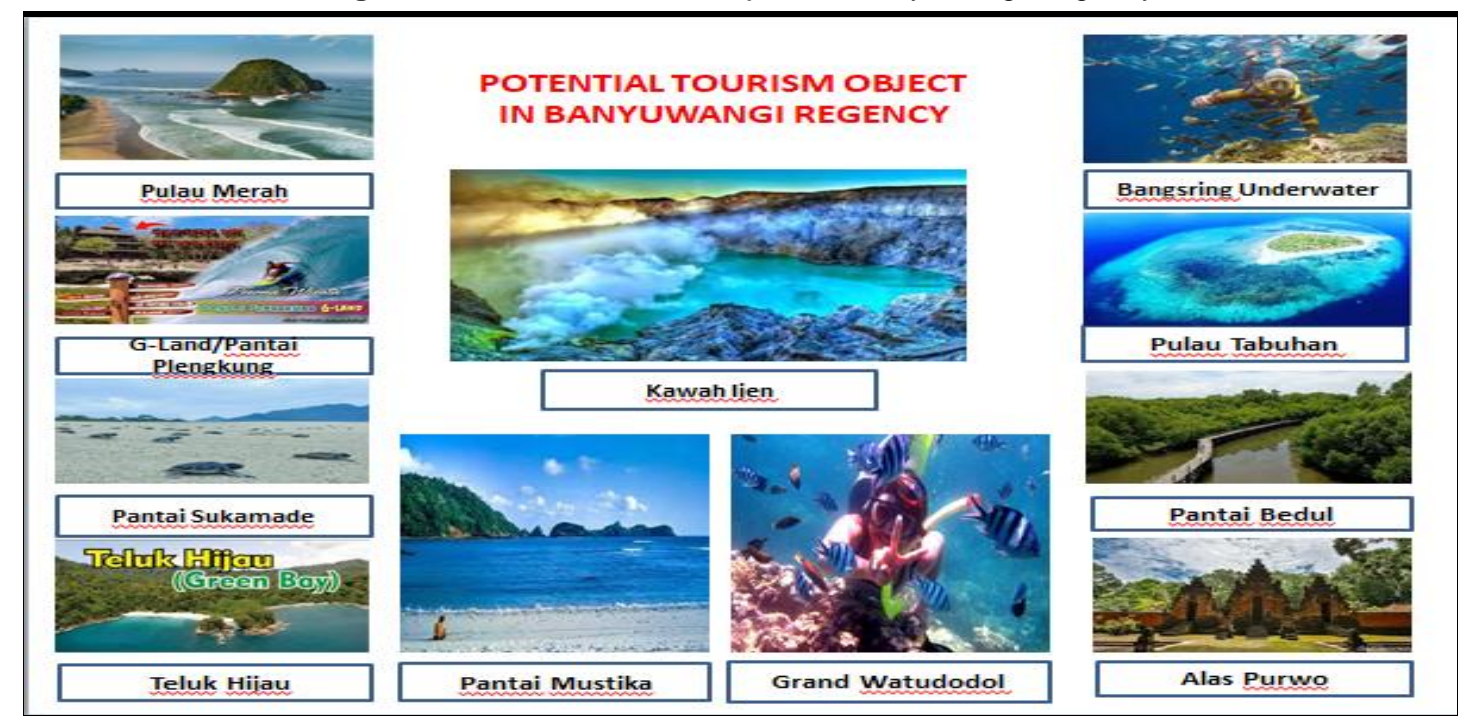

The increase in development was supported by $25 \%$ from the trade, hotel and restaurant sectors, construction, services, and finance, which were the sectors that most strongly contributed to the net shift with a total of more than 25 percent. Identification of investment priorities in these potential sectors and implementation of a comprehensive regional development policy plan will surely accelerate Banyuwangi's economic growt (Khusaini, 2015). The following is data on tourist visits to Banyuwangi Regency from 2016 to 2019.

Figure 2 Banyuwangi Regency Tourist Visits Data 2016 - 2019

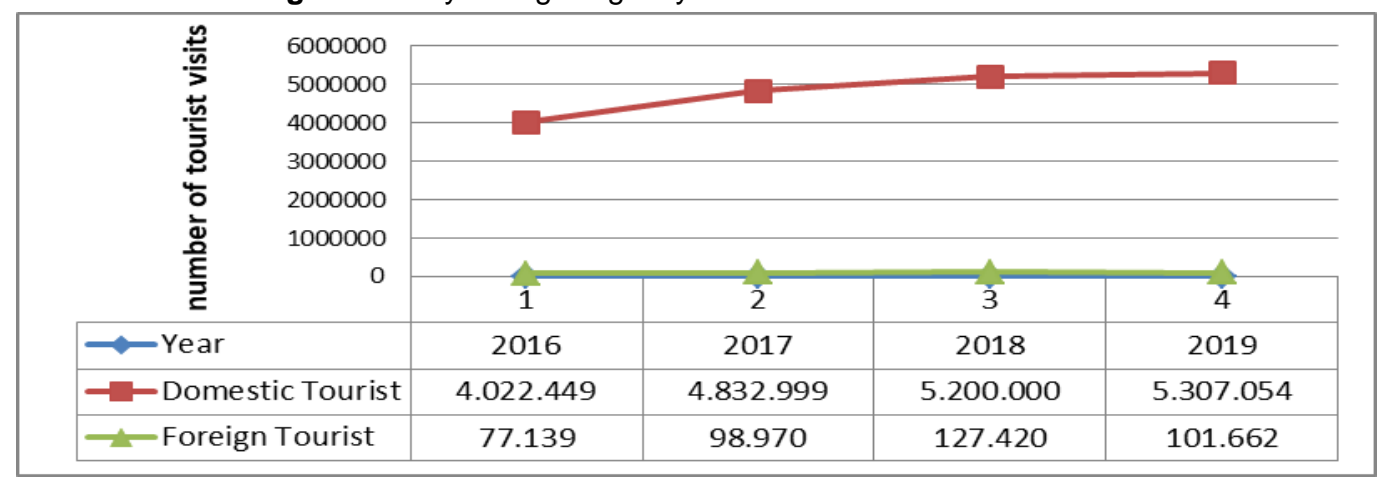

Source: Pemerintah Kabupaten Banyuwangi (2021)

A similar opinion was conveyed by Puspita Sari et al. (2019), that in 2016 Banyuwangi won the UNWTO Awards for Excellence and Innovation in Tourism for the category "Public Policy Innovation and Governance" from the United Nations World Tourism Organization (UNWTO). This award proves that Banyuwangi's tourism policy has been recognized worldwide. Tourism development is an effort of the government to promote.

Other tourism potentials in Banyuwangi are culture and artistic diversity (Bappeda Kabupaten Banyuwangi, 2020) which are getting stronger as the promotion of international go-tourism is growing. The collaboration between the two is considered to be in line with the encouragement of local government synergy in encouraging the improvement of community welfare. Such as the Geridhoan and Endhog-Endhogan cultural traditions which were developed in Increasing Sharia Tourism Attractiveness through the Geridhogan Festival in Banyuwangi.(Robis et al., 2019) In addition, cultural potential such as the Gandrung Sewu Festival, Seblang, Kebo-keboan, and other festivals that serve as the power of Banyuwangi Tourism which is made in the form of an event calendar and Banyuwangi Festival (Kurniawan, n.d.) 


\subsection{Financial Analysis}

The approach used to determine the feasibility of developing a tourism business is financial analyses which, according to Currie et al. (2009), can identify and explore potential business feasibility for stakeholders in a systematic manner in the feasibility analysis. The five financial analyses used in the study for 11 leading tourism objects that have been determined by the Banyuwangi Regency Government RUPM (General Investment Plan) in 2019 produced the following data:

Table 3 Financial Analysis Results 1

\begin{tabular}{|c|c|c|c|c|}
\hline \multirow{2}{*}{ No. } & \multirow{2}{*}{ Financial Analysis } & \multicolumn{3}{|c|}{ Tourism objects } \\
\hline & & Red Island & G-Land Plengkung & Sukamade Beach \\
\hline 1 & Payback Period (PP) & $\begin{array}{c}\text { In Year } 7 \\
\text { Rp107,224,142,212 }\end{array}$ & $\begin{array}{c}\text { In year } 3 \\
\text { Rp98.087.267 }\end{array}$ & $\begin{array}{c}\text { In Year } 5 \\
\text { Rp54.109.250 }\end{array}$ \\
\hline 2 & $\begin{array}{c}\text { Average Rate of Return } \\
\text { (ARR) }\end{array}$ & $12.79 \%$ & $13.40 \%$ & $12.06 \%$ \\
\hline \multirow{3}{*}{3} & NPV (Net Present Value) & Rp766.445.444>0 & Rp408.628.724>0 & Rp86.842.766>0 \\
\hline & NET B/C & Net $B / C 1.05>1$ & Net $B / C 2.10>1$ & Net $B / C 1.20>1$ \\
\hline & GROSS B/C & $\begin{array}{l}\text { Value } 1.0029 ; \mathrm{B} / \mathrm{C} \\
\text { ratio }>1\end{array}$ & $\begin{array}{l}\text { Value } 1.0072 ; \mathrm{B} / \mathrm{C} \\
\text { ratio }>1\end{array}$ & $\begin{array}{c}\text { Value } \\
1.2207 ; \mathrm{B} / \text { Cratio }>1\end{array}$ \\
\hline 4 & $\begin{array}{l}\text { Internal Rate of Return } \\
\text { (IRR) }\end{array}$ & $12.8 \%(>11 \%)$ & $11.76 \%(>11 \%)$ & $11.75 \%(>11 \%)$ \\
\hline \multirow[t]{2}{*}{5} & Profitability Ratio & Rp230.744.763.552>1 & Rp142.605.103.362>1 & Rp120.309.663>1 \\
\hline & $\begin{array}{c}\text { Results and } \\
\text { Recommendations }\end{array}$ & $\begin{array}{l}\text { The project is feasible } \\
\text { to implement. }\end{array}$ & $\begin{array}{l}\text { The project is feasible } \\
\text { to implement. }\end{array}$ & $\begin{array}{c}\text { The project is feasible } \\
\text { to implement. }\end{array}$ \\
\hline
\end{tabular}

Based on Table 3, it is explained that for the Red Island Tourism object, G-Land Plengkung, Sukamade Beach, judging from the Payback Period analysis, the results can be obtained up to 3 years and a maximum of 7 years. All of them are profitable, thus worthy of investment.

Table 4 Financial Analysis Results 2

\begin{tabular}{|c|c|c|c|c|}
\hline \multirow{2}{*}{ No. } & \multirow{2}{*}{ Financial Analysis } & \multicolumn{3}{|c|}{ Tourism objects } \\
\hline & & Green Bay & Mustika Beach & ljen Crater \\
\hline 1 & Payback Period (PP) & $\begin{array}{c}\text { In Year } 3 \\
\text { Rp59.207.440 }\end{array}$ & $\begin{array}{c}\text { In Year } 4 \\
\text { Rp38.883.900 }\end{array}$ & $\begin{array}{c}\text { In Year } 4 \\
\text { Rp110.450.274. }\end{array}$ \\
\hline 2 & $\begin{array}{c}\text { Average Rate of Return } \\
\text { (ARR) }\end{array}$ & $11.18 \%$ & $11.43 \%$ & $11.99 \%$ \\
\hline \multirow{3}{*}{3} & NPV (Net Present Value) & Rp98.209.009>0 & Rp130.228.180>0 & Rp390.960.120.405>0 \\
\hline & NET B/C & Net B/C $1.07>1$ & Net B/C 1.01>1 & Net B/C 1.12>1 \\
\hline & GROSS B/C & Value1.02; B/C ratio>1 & $\begin{array}{l}\text { Value } 1.109 ; \mathrm{B} / \mathrm{C} \\
\text { ratio }>1\end{array}$ & $\begin{array}{l}\text { Value } 1.306 ; \mathrm{B} / \mathrm{C} \\
\text { ratio }>1\end{array}$ \\
\hline 4 & $\begin{array}{l}\text { Internal Rate of Return } \\
\text { (IRR) }\end{array}$ & $11.28 \%(>11 \%)$ & $11.95 \%(>11 \%)$ & $11.88 \%(>11 \%)$. \\
\hline \multirow[t]{2}{*}{5} & Profitability Ratio & Rp88.306.863>1 & Rp146.603.981>1 & Rp187.155.926>1 \\
\hline & $\begin{array}{c}\text { Results and } \\
\text { Recommendations }\end{array}$ & $\begin{array}{l}\text { The project is feasible } \\
\text { to implement. }\end{array}$ & $\begin{array}{l}\text { The project is feasible } \\
\text { to implement. }\end{array}$ & $\begin{array}{c}\text { The project is feasible } \\
\text { to implement. }\end{array}$ \\
\hline
\end{tabular}


Table 4 also explains that for Green Bay, Mustika Beach, and ljen Crater, the Payback Period can be obtained up to 3-4 years and very profitable for investors. The highest profitability is of the ljen Crater tourist attraction, which is a leading tourist attraction in Banyuwangi Regency. From the results of the analysis, the three tourism objects are feasible to get investment capital.

Table 5 Financial Analysis Results 3

\begin{tabular}{|c|c|c|c|c|}
\hline \multirow{2}{*}{ No. } & \multirow{2}{*}{ Financial Analysis } & \multicolumn{3}{|c|}{ Tourism objects } \\
\hline & & Grand Watudodol & $\begin{array}{l}\text { Bangsring } \\
\text { Underwater }\end{array}$ & Bedul Beach \\
\hline 1 & Payback Period (PP) & $\begin{array}{c}\text { In Year 4; } \\
\text { Rp139.460.338 }\end{array}$ & $\begin{array}{c}\text { In Year 2; } \\
\text { Rp115.870.506 }\end{array}$ & $\begin{array}{c}\text { In Year 3; } \\
\text { Rp47.224.142 }\end{array}$ \\
\hline 2 & $\begin{array}{c}\text { Average Rate of Return } \\
\text { (ARR) }\end{array}$ & $12.52 \%$ & $11.88 \%$ & $11.65 \%$ \\
\hline \multirow{3}{*}{3} & NPV (Net Present Value) & Rp193.174.329>0 & Rp75.920.275>0 & Rp129.007.180>0 \\
\hline & NET B/C & Net B/C 2.04>1 & Net B/C 1.09>1, & Net B/C 1.09>1, \\
\hline & GROSS B/C & $\begin{array}{l}\text { Value } 1.3066 ; \mathrm{B} / \mathrm{C} \\
\text { ratio>1 }\end{array}$ & $\begin{array}{c}\text { Value } 1.209 ; \mathrm{B} / \mathrm{C} \\
\text { ratio }>1\end{array}$ & $\begin{array}{c}\text { Value } 1.0029 ; B / C \\
\text { ratio }>1\end{array}$ \\
\hline 4 & Internal rate of Return (IRR) & $11.88 \%(>11 \%)$. & $11.73 \%(>11 \%)$ & $12.80 \%(>11 \%)$. \\
\hline 5 & Profitability Ratio & Rp330.920.985>1 & Rp60.922.670>1 & Rp142.080.269>1 \\
\hline \multicolumn{2}{|r|}{ Results and Recommendations } & $\begin{array}{c}\text { The project is feasible } \\
\text { to implement. }\end{array}$ & $\begin{array}{l}\text { The project is } \\
\text { feasible to } \\
\text { implement. }\end{array}$ & $\begin{array}{c}\text { The project is feasible } \\
\text { to implement. }\end{array}$ \\
\hline
\end{tabular}

The results of the financial analysis in Table 5 explain that for the Grand Watudodol, Bangsring Underwater, and Bedul Beach attractions, the Payback Period can be achieved 2-4 years. The Bangsring Underwater tourist attraction can get it fastest: only 2 years. All of them are profitable for investors. Therefore, the three attractions are worthy of investment capital.

Table 6 Financial Analysis Results 4

\begin{tabular}{|c|c|c|c|}
\hline \multirow{2}{*}{ No. } & \multirow{2}{*}{ Financial Analysis } & \multicolumn{2}{|c|}{ Tourism objects } \\
\hline & & Tabuhan Island & Alas Purwo \\
\hline 1. & Payback Period (PP) & in Year 3, value:Rp60.128.200 & In Year 3, Value: Rp112.825.700. \\
\hline 2. & $\begin{array}{c}\text { Average Rate of Return } \\
\text { (ARR) }\end{array}$ & $11.65 \%$ & $11.38 \%$ \\
\hline \multirow{3}{*}{3.} & NPV (Net Present Value) & Rp96.289.40>0 & Rp165.287.050>0 \\
\hline & NET B/C & Net $B / C 1.10>1$ & Net B/C 1.25>1 \\
\hline & GROSS B/C & Value $1.0085 ; \mathrm{B} / \mathrm{C}$ ratio $>1$ & Value $1.0080 ; \mathrm{B} / \mathrm{C}$ ratio $>1$ \\
\hline 4. & Internal Rate of Return (IRR) & $11.48 \%(>11 \%)$ & $12.90 \%(>11 \%)$ \\
\hline 5. & Profitability Ratio & Rp100.295.482>1 & Rp100.162.300>1 \\
\hline \multicolumn{2}{|c|}{ Results and Recommendations } & $\begin{array}{c}\text { The project is feasible to } \\
\text { implement. }\end{array}$ & $\begin{array}{c}\text { The project is feasible to } \\
\text { implement. }\end{array}$ \\
\hline
\end{tabular}

The results of the latest financial analysis, as shown in Table 6, show that for Tabuhan Island and Alas Purwo tourism objects, the results of the Payback Period analysis reach 3 years, and are profitable for investors. From the results of the analysis, the two attractions are also eligible for investment capital. 
Based on the results of financial analysis and interviews at tourism object locations as well as with the Banyuwangi Regency government, judging from the previous sources of investors and judging from the existing prospects, a very profitable way for the Banyuwangi Regency government to obtain investment funds is to withdraw funds from individual and institutional investors. The most important investment effect, namely for financing capital in potential sectors that can increase regional growth, is expressed in the revitalization of working capital, strengthening the investment process, as well as the formation of new trends in regional and national economic development.

Investment is hoped to be able to accelerate technological progress through the use of new technologies, transfer the experience of market relations developed in relation to the capital markets of importing countries, and improve the structure of the economy with a focus on modern and industrial sectors for more efficient use of all labor and natural resources. In developing the potential of Global Tourism, government support is very important as stated by Bhattacheryay, (2018) where the Government of India supports and greatly simplifies Foreign Investment rules so that the ultimate goal is to attract more investors without danger. In addition, in investment, it is also necessary to open investment and technology as well as international market facilities so that economic growth increases and exports increase, this was conveyed by (Sharmiladevi, 2020). Meanwhile, to anticipate disputes related to investment, a strong analysis is needed so that there are no disputes in investment To run it all needed a strong organization and management that affect the decision of investors in investing (Putra et al., 2020). The development program to increase the attractiveness of tourism needs a development concept by following the era of globalization without reducing its historical value to attract visitors to be ready to face competition between tourist objects (Runtunuwu, 2020).

The same thing was conveyed by Rustamov (2019), that investment has an important role in further deepening the process of structural transformation in the economy and accelerating company investment activities, modernization of production, technical equipment, and technology. At the same time, it is possible to introduce advanced technologies, create new jobs and, on this basis, ensure the sustainable development of the country's economy and the advancement of the country.

The results of the financial analysis show that investment in the tourism sector has a very large opportunity to increase the economy in Banyuwangi Regency where tourism can trigger other sectors to grow and develop as well. This is in accordance with what was conveyed by Scott et al. (2012), that Tourism is a major global economic sector that is experiencing tremendous growth in developing countries and is often cited as a prominent factor for development and poverty alleviation in developing countries.

Based on the results of the analysis, there are three investment priorities in potential sectors that will certainly accelerate Banyuwangi's economic growth, namely the first in Bangsring Underwater Destinations with Payback Period (PP) In Year 2; with a value of Rp115,870,506, the second recommendation is Alas Purwo Destination with a Payback Period (PP) In Year 3, with a Value: Rp112,825,700 and the third recommendation is ljen Crater with a Payback Period (PP) In Year 4 with a value of $R p 110,450,274$.

\section{Conclusion}

After identifying tourism potential in the investment development strategy in Banyuwangi Regency by analyzing eleven tourism objects with three analysis tools, the researchers concluded that, overall, the tourism objects are feasible and profitable for investment. Tourism in Banyuwangi Regency consists of nature tourism and organized local or international events. The number of tourists visiting it increases year by year; most of them are domestic tourists. The financial ratios of Banyuwangi's leading tourist destinations are worthy of investments. 
1. Al Mudhayan, A., Alajmi, R., Betancur, S. L., \& Al Shamlan, A. A. (2019). SABIC-Petrochemical Manufacturing Company. Asia Pacific Journal of Management and Education (APJME), 2(3), 6769.

2. Axmedova, Z. (2020). ПСИХОЛОГИЧЕСКИЕ ОСНОВЫ РАЗВИТИЯ ВОЗМОЖНОСТЕЙ ИНТЕЛЛЕКТУАЛЬНОГО ТВОРЧЕСТВА МОЛОДЕЖИ В ОБРАЗОВАТЕЛЬНОМ ПРОЦЕССЕ. ЦЕНТР НАУЧНЫХ ПУБЛИКАЦИЙ (Buxdu. Uz), 1(1).

3. Badan Pusat Statistik Indonesia. (2021). Produk Domestik Regional Bruto Provinsi-Provinsi di Indonesia. https://www.bps.go.id/publication/2020/04/30/b792420b4ec3849e5ed29ea3/produkdomestik-regional-bruto-provinsi-provinsi-di-indonesia-menurut-lapangan-usaha-2015-2019.html

4. Bappeda Kabupaten Banyuwangi. (2020). Program Seni Budaya Banyuwangi Harus Dorong Kesejahteraan Masyarakat. https://bappeda.banyuwangikab.go.id/page/berita/program-senibudaya-banyuwangi-harus-dorong-kesejahteraan-masyarakat

5. Basila, D. (2010). Investigating the Relationship between VAT and GDP in Nigerian Economy. Journal of Management and Corporate Governance, 2 (2), 65, 72.

6. Bennett, N., Lemelin, R. H., Koster, R., \& Budke, I. (2012). A capital assets framework for appraising and building capacity for tourism development in aboriginal protected area gateway communities. Tourism Management, 33(4), 752-766.

7. Bhattacheryay, S. (2018). Foreign direct investment in India opportunities and challenges. International Journal of Asian Business and Information Management (IJABIM), 9(4), 1-20.

8. Currie, R. R., Seaton, S., \& Wesley, F. (2009). Determining stakeholders for feasibility analysis. Annals of Tourism Research, 36(1), 41-63.

9. Fikri, H. (2017). Inovasi Pemerintahan Kabupaten Banyuwangi Melalui City Branding "The Sunrise Of Java" Sebagai Strategi Pemasaran Pariwisata. Aristo, 5(2), 332-344.

10.Ghazoul, J., Butler, R. A., Mateo-Vega, J., \& Koh, L. P. (2010). REDD: a reckoning of environment and development implications. Trends in Ecology \& Evolution, 25(7), 396-402.

11.Indrajaya, I. G. B., \& Devi, I. A. W. P. (2014). Analisis Kebutuhan Investasi Sektor Potensial di Kabupaten Buleleng. E-Jurnal Ekonomi Pembangunan Universitas Udayana, 3(12), 44500.

12.Kee, D. M. H., Chee, C. K., Ng, C., \& Yao, T. (2019). Analysis of Challenges faced by Huawei on the launching of $5 \mathrm{G}$ Technology and the Strategies to Overcome it. Asia Pacific Journal of Management and Education (APJME), 2(3), 37-44.

13.Khusaini, M. (2015). A shift-share analysis on regional competitiveness-a case of Banyuwangi district, East Java, Indonesia. Procedia-Social and Behavioral Sciences, 211, 738-744.

14.Kim, H., Sefcik, J. S., \& Bradway, C. (2017). Characteristics of qualitative descriptive studies: A systematic review. Research in Nursing \& Health, 40(1), 23-42.

15.Knollenberg, W., Brune, S., Harrison, J., \& Savage, A. E. (2021). Identifying a community capital investment portfolio to sustain a tourism workforce. Journal of Sustainable Tourism, 1-17.

16. Kurniawan, F. (n.d.). Pelaksanaan Promosi Banyuwangi Festival Sebagai Daya Tarik Wisatawan Di Kabupaten Banyuwang.

17.Lasindrang, L. S. N. K. M. (2015). Kajian Sebaran Potensi Ekonomi Sumber Daya. Jurnal Teknosains, $4(2)$.

18.Li, K. X., Jin, M., \& Shi, W. (2018). Tourism as an important impetus to promoting economic growth: A critical review. Tourism Management Perspectives, 26, 135-142.

19.Lopez, V., \& Whitehead, D. (2013). Sampling data and data collection in qualitative research. Nursing \& Midwifery Research: Methods and Appraisal for Evidence-Based Practice, 123-140.

20.M.Liga Suryana and Vanny Octavia. (2015). Pengantar Pemasaran Pariwisata.

21.Murphy, P. (2013). Tourism: A community approach (RLE Tourism). Routledge.

22.Pemerintah Kabupaten Banyuwangi. (2021). Tourism Data.

https://banyuwangikab.go.id/profil/pariwisata.html

23.Pusparajan, A., Das, L. A., Kee, D. M. H., Amirah, N., Alrashidi, A., Quttainah, M. A., Alosaimi, A., 
Verma, D., \& Pandey, R. (2020). The Rise and Fall Ali Baba Company Has Encountered Throughout Their Success. Asia Pacific Journal of Management and Education (APJME), 3(2), 11-21.

24.Puspita Sari, I. S., Pangestuti, E., \& Supriono, S. (2019). Analisis Dampak City Branding Terhadap Kunjungan Wisatawan Ke Kabupaten Banyuwangi (Studi pada Dinas Kebudayaan dan Pariwisata Kabupaten Banyuwangi). Jurnal Administrasi Bisnis, 72(1), 63-72.

25.Putra, G. B. B., Sudharma, I. W. P. A., \& Rahmadani, D. A. (2020). Key Variables on Property Marketing in Bali: Application of Micmac Method. Asia Pacific Journal of Management and Education (APJME), 3(1), 28-34.

26.Putri, I. (2015). Implementasi Rencana Strategis Pengembangan Obyek Wisata Unggulan Taman Wisata Alam Kawah ljen (Studi di Dinas Kebudayaan dan Pariwisata Kabupaten Banyuwangi). Universitas Brawijaya.

27.Rizaly, E. N., \& Rahman, A. (2021). Pengembangan Sistem Informasi Pariwisata Berbasis Website Untuk Meningkatkan Kesadaran Masyarakat Terhadap Potensi Daerah Kabupaten Dompu. Jurnal Penelitian Dan Pengabdian Masyarakat Bidang Pariwisata, 1(1), 29-38.

28.Robis, M., Fachrezzi, B. R., \& Akhsan, A. (2019). Pengembangan Tradisi Geridhoan dan EndhogEndhogan dalam Meningkatkan Daya Tarik Wisata Syariah melalui Festival GERIDHOGAN di Banyuwangi. Dinar: Jurnal Ekonomi Dan Keuangan Islam, 6(2), 123-134.

29.Runtunuwu, P. C. H. (2020). Tourism sector development strategy in North Maluku: A case study of Tidore Islands. International Journal of Tourism and Hospitality in Asia Pasific (IJTHAP), 3(3), 18.

30.Rustamov, D. J. (2019). THE ROLE OF INVESTMENT IN SMALL BUSINESS AND PRIVATE ENTREPRENEURSHIP. Столица Науки, 29.

31.Scott, D., Gössling, S., \& Hall, C. M. (2012). International tourism and climate change. Wiley Interdisciplinary Reviews: Climate Change, 3(3), 213-232.

32.Sharmiladevi, J. C. (2020). Cointegration and Causality Study Among Inward FDI, Economic Growth and Exports: An Indian Perspective. International Journal of Asian Business and Information Management (IJABIM), 11(1), 63-77.

33.Skidmore, M., \& Scorsone, E. (2011). Causes and consequences of fiscal stress in Michigan cities. Regional Science and Urban Economics, 41(4), 360-371.

34.Sugiarto, E. (2017). Menyusun Proposal Penelitian Kualitatif: Skripsi dan Tesis: Suaka Media. Diandra Kreatif.

35.Tang, C. F. (2021). The threshold effects of educational tourism on economic growth. Current Issues in Tourism, 24(1), 33-48.

36. Wiweka, K., \& Arcana, K. T. P. (2017). Rethinking the Theory of Tourism: What is Tourism System in Theoretical and Empirical Perspective? 